\title{
IDENTIFICATION OF EXPLORATION GOLD TARGETS IN THE ALTA FLORESTA GOLD PROVINCE, MATO GROSSO STATE, BRAZIL, BASED ON AN INTEGRATED INTERPRETATION OF MAGNETIC AND GEOELECTRICAL DATA
}

\author{
Ethiane Agnoletto and Emilson Pereira Leite
}

\begin{abstract}
The significant amount of filonean bodies in the gold mining area of Flor da Serra, east portion of the Alta Floresta Gold Province, located in the state of Mato Grosso, Brazil, and the production history of the area indicates high potential for gold exploration. Our work aimed to identify new gold exploration targets in this area through the analysis and interpretation of geoelectric and magnetic data, constrained by descriptions of drill core samples and prospecting pits. The geophysical survey consisted of the acquisition of geoelectrical (induced polarization/resistivity) and magnetic data at deposit scale. Anomalous values of chargeability and resistivity defined zones of intense silicification and quartz-sericite-pyrite alteration closely related to a disseminated ore type, extending far below the saprolite-bedrock interface. The amplitude of the analytic signal of the magnetic anomalous field allowed the identification of granitic intrusive stock within heterogeneous basement. Magnetic structures were extracted from magnetic anomalies reduced to the equator over which directional features were highlighted after application of a directional cosine filter and upward continuation. The structural pattern is associated with different crustal levels, controls the main filonean bodies of the region and is attached to quartzsericite-pyrite alteration. The integrated interpretation of main structural lineaments; zones of high chargeability/resistivity; detailed mapping of deactivated mining pits; and boundaries of the intrusion zone led to the definition of some prospective gold targets.
\end{abstract}

Keywords: magnetometry, induced polarization, resistivity, gold deposits.

RESUMO. A quantidade significativa de corpos filoneanos na área de mineralizações auríferas de Flor da Serra, porção leste da Província Aurífera de Alta Floresta (PAAF), localizada no estado de Mato Grosso, e o histórico de produção dessa área indicam alto potencial para exploração de ouro. Este trabalho teve como objetivo identificar novos alvos de exploração de ouro nesta área, através da análise e interpretação dos dados geoelétricos e magnéticos, vinculados por descrições de amostras de testemunhos de perfuração e de cavas garimpeiras. 0 levantamento geofísico consistiu na aquisição de dados geoelétricos de polarização induzida/resistividade e magnéticos em escala de depósito. Valores anômalos de cargabilidade e zonas de resistividade definiram intensa silicificação e alteração quartzo-sericita-pirita (QSP) fortemente relacionadas a um tipo de minério disseminado, estendendo-se muito abaixo da interface saprólito-rocha. A amplitude do sinal analítico do campo magnético anômalo permitiu a identificação de um stock granítico intrusivo dentro de um embasamento heterogêneo. Estruturas magnéticas foram extraídas de anomalias magnéticas reduzidas ao equador magnético, sobre as quais as principais feições direcionais foram destacadas após aplicação de um filtro de cosseno direcional e continuação para cima. 0 padrão estrutural, que está associado a diferentes níveis crustais, controla os principais corpos filoneanos da região e está ligado à alteração de QSP. A interpretação integrada dos principais lineamentos estruturais; zonas de alta cargabilidade/resistividade; mapeamento detalhado de cavas garimpeiras desativadas; e zona limítrofe da intrusão, levou à definição de alguns alvos potenciais para exploração de ouro.

Palavras-chave: magnetometria, polarização induzida, resistividade, depósitos de ouro. 


\section{INTRODUCTION}

The Alta Floresta Gold Province (AFGP), located in the centralnorth of the state of Mato Grosso, is composed of dozens of gold mining. Among them, the Flor da Serra area stood out because of an expressive spatial density of filonean bodies and a considerable amount of secondary deposits, which made the gold production to grown in recent years. However, there is room for finding new exploration targets and keeping the production growing, especially because some primary bodies were abandoned by mining companies but they have the potential to host secondary deposits. The gold mining area of Flor da Serra is I0cated between Braço Norte and Peixoto rivers and belongs to the city of Matupá. This area is encompassed in the Vila Guarita (SC.21-Z-B) cartographic chart produced by the Geological Survey of Brazil (Moreton \& Martins, 2005) in between latitudes $10^{\circ} 00^{\prime} / 11^{\circ} 00^{\prime} \mathrm{S}$ and longitutdes $54^{\circ} 00^{\prime} \mathrm{W} / 55^{\circ} 30^{\prime} \mathrm{W}$ (Fig. 1).

A deep weathered zone in the Flor da Serra area prevents a traditional geological mapping at a scale that is adequate for a detailed mineral exploration research. In such cases, several indirect geophysical methods has been commonly applied (e.g. Irvine \& Smith, 1990; Ranjbar et al., 2001; Meju, 2002; Barbuena et al., 2013). These methods have a low environmental impact and acquisitions can be performed very fast at a relatively low cost.

Particularly, the interpretation of magnetic anomalies through various techniques has been extensively used to the detection and mapping of geological structures to which gold mineralizations are associated. For example, Holden et al. (2008) present an algorithm to automatic detection of magnetic structures based on local texture, which is tested using aeromagnetic data from the Yilgarn Craton in Western Australia; Leite et al. (2009) used interpreted magnetic structures in a neural network algorithm to predict areas of high favorability for the occurrence of $\mathrm{Cu}-\mathrm{Au}$ mineralizations. Zhao et al. (2011) show that fractal and multifractal analysis are effective tools for mapping complexity in the spatial distribution of faults, particularly faults within the Yunnan province in China; structural controls on a magnetite-rich iron oxide copper-gold deposit in northwest Queensland, Australia, and the relationships between structures, alteration, $\mathrm{Fe}$ oxides and mineralization at core to deposit scales were investigated by Austin et al. (2013).

On the other hand, geoelectrical methods of induced polarization (IP) and resistivity (RES) have been useful to the identification of metallic minerals such as pyrite, chalcopyrite and pyrrhotite. This is demonstrated in Oldenburg et al. (1997), where the authors inverted the RES, IP, magnetic and electromagnetic data from the Mt. Milligan copper-gold porphyry deposit and jointly interpreted the inversion results, taking into account the available geological and mineralization data; Daneshvar Saein et al. (2012) applied a fractal method based on IP and RES data to separate high and moderate sulfidic zones from a low sulfidic zone and barren wall rocks in targeting areas hosting different sulfide mineralization zones, in the Nowchun Cu-Mo porphyry deposit, SE Iran; and Jang et al. (2014) inverted geoelectrical data acquired in the Haenam epithermal mineralized area, Korea, obtaining a constrained model that indicates a fine-grained pyrite disseminated in a shallow zone.

In this work, local geological unities were defined from descriptions of core samples, field surveys, mapping of pits and mining galleries. New exploration targets related to filonean and disseminated gold mineralizations in the study area (Fig. 1) were identified by an integrated analysis of magnetic anomalies and geoelectric data, which were correlated with the local geological units. The magnetic structures were extracted after reducing the magnetic anomalous field to the equator and applying a directional cosine filter. Reduction to the equator is recommended at middle and lower latitudes and synthetic calculations have shown that a "reduced to the equator" magnetic field is less complex and more accurate than a "reduced to the pole" magnetic field (Jain, 1988). The local geological units were correlated with anomalies observed in the amplitude of the analytic signal map.

\section{GEOLOGICAL SETTING}

AFGP is located in the central-southern portion of the Amazonian craton. In terms of tectonic framework, depending on the adopted model, it is considered to be part of the geochoronologic provinces of Ventuari-Tapajós (1.95-1.55 Ga) and Rio Negro-Juruena (1.8-1.55 Ga) according to Tassinari \& Macambira (1999); or part of the Tapajós-Parima (2.03-1.88 Ga) and Rondônia-Juruena (1.82-1.54 Ga) according to Santos (2006). Rocks of those areas are classified as the ductile-ruptile deformed volcanic-plutonic rocks of the Juruena magmatic arch (1.851.75 Ga; T $1.85-1.75$ Ga; Lacerda Filho (2004) and Souza et al. (2005)). An archean heterogeneous basement with post-tectonic paleoproterozoic calc-alkaline to sub-alkaline granitic intrusions is observed (Paes de Barros, 2007). Nd model ages ( $T_{D M}$ ) for this granites fall in the range 2.3-2.6 Ga and $\varepsilon_{\mathrm{Nd}}(\mathrm{t})$ are between -3.4 and $-7.62 \mathrm{Ga}$. Most of the gold deposits ( $\mathrm{Au} \pm \mathrm{Cu}$ ) are distributed along NW-SE structures of multiple transcurrent zones and are hosted by basement granitic and gneissic rocks.

Particularly, Flor da Serra is located in the northwestern portion of AFGP (Fig. 1) and the geological units are subdivided as follows.

The Xingu Complex is composed of tonalitic to granodioritic gneissic units whose metamorphic foliations are ori- 


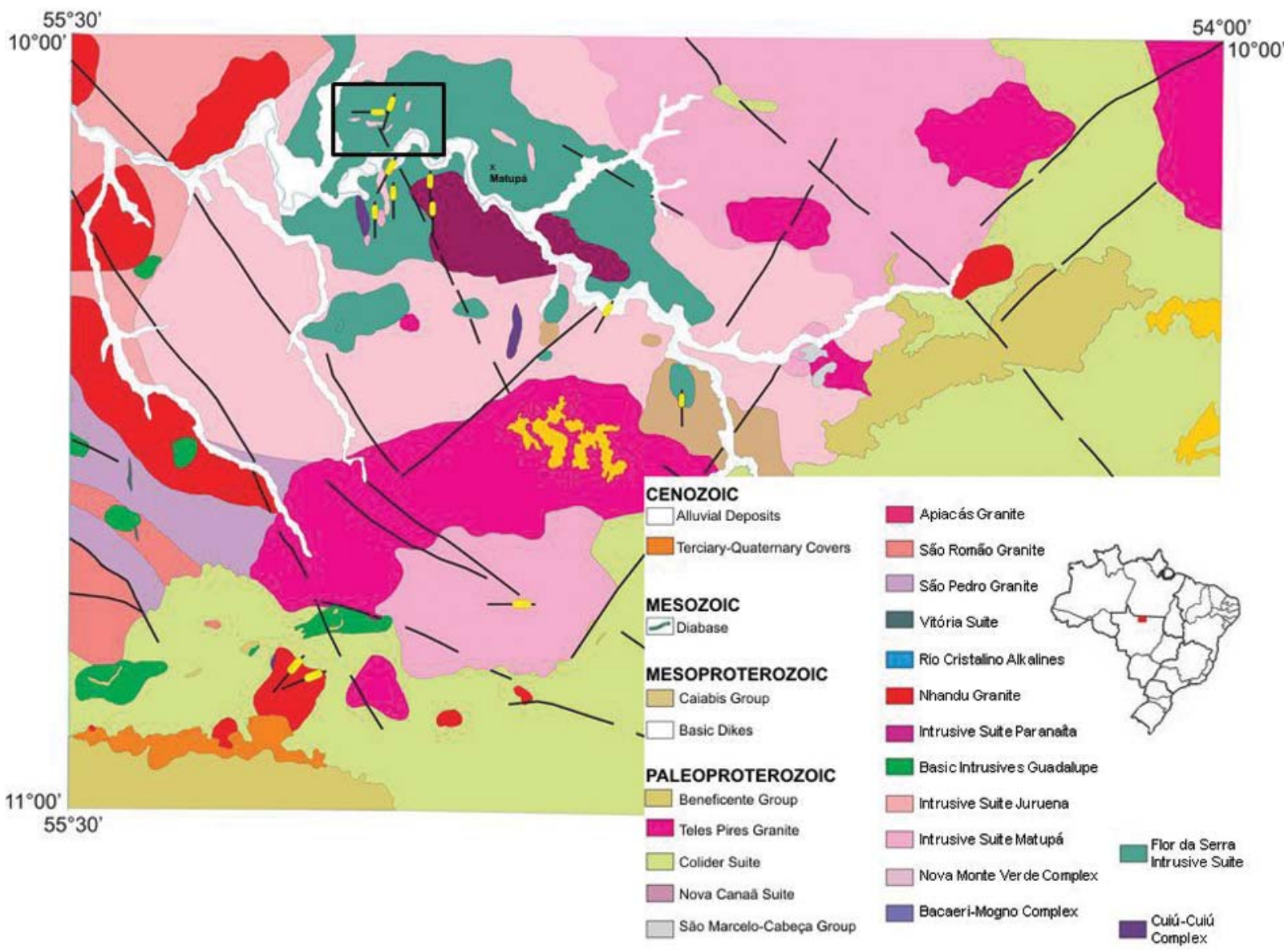

Figure 1 - Geological map of the AFGP (adapted from Moreton \& Martins (2005)). Black rectangle delimits the area where ground geophysical data was collected.

ented along NNE-SSW to NNW-SSE directions. Associated with these gneisses are some talc-chlorite/phlogopite/chlorite-sericite schists, as well as ultramafic rocks and amphibolites (Dardenne \& Schobbenhaus, 2001). In this portion of the AFGP, Paes de Barros (2007) has dated one of the gneissic rocks as (2816 \pm 4) Ma using $\mathrm{Pb}-\mathrm{Pb}$ zircon dating.

The Pé Quente Intrusive Suite consists of equigranular to porphyry rocks of granitic, monzonitic and granodioritic composition with magnetite-hornblend-biotite, truncated by basic volcanic dikes (Assis, 2011). Monzonite and quartz-monzodiorite are associated with disseminated gold mineralization and locally with quartz veins and stockworks. SHRIMP U-Pb zircon dating from monzonite samples indicates a crystallization age of (1.979 \pm 31 ) Ma (Miguel Jr., 2011).

Novo Mundo Granite is a $60 \mathrm{~km}^{2}$ NWW-SEE elongated intrusive body in basement rocks. This orientation is coincident with the directions of the main ductile shear zones and regional lineaments. The southern portion of this granitic body is where disseminated gold mineralizations are found.
The Aragão Granite is a $100 \mathrm{~km}^{2} \mathrm{NE}-\mathrm{SW}$ elongated intrusive body composed of approximately isotropic syenogranite and monzogranite with granitic porphyry to medium-grained phaneritic facies as well as microgranitic facies (Vitorio, 2010). There are dozens of partially explored filoneans gold deposits controlled by structures of a sinistral transcurrent shear zones on the northern and northeastern portion of this body (Miguel Jr., 2011).

The Nhandu Granite (1889-1879 Ma) is composed of magnetite-biotite monzogranite and syenogranite with calcalkaline affinity, having diorite to quartz monzodiorite enclaves, subordinated subvolcanic granites, fine-grained quartz syenite and granophyres (Moreton \& Martins, 2005; Souza et al., 2005).

The Matupá Intrusive Suite (1884-1860 Ma) is subdivided into four facies with monzogranitic to granitic compositions (Moreton \& Martins, 2005; Souza et al., 2005). Facies 1 and 2 are where gold mineralizations are found; rocks of Facies 3 forms a red soil due to the presence of magnetic monzodiorites; and Facies 4 is the largest one. Facies 1 is cut by felsic ryolitic dikes that are co-genetic with the granitic magmatism, and by mafic 
dikes that have geochemical signature similar to that of continental tholeiitic basalts (Moura et al., 2006). Facies 2, 3 and 4 are intruded by the Teles Pires Granite and rocks of the Flor da Serra Intrusive Suite and are covered by volcanic rocks of the Colíder Suite.

The Flor da Serra Intrusive Suite is composed of porphyry gabbros, olivine gabbros, monzogabbros, diabase porphyry, diorites, gabbro-diorites and monzodiorites parcially transformed into anphibolites, as well as subordinated andesites and trachyandesites (Moreton \& Martins, 2005). Complementary geological data suggests that these rocks were intruded into the Matupá Suite (Moreton \& Martins, 2005). The age of this Suite is uncertain (Assis, 2011).

The Peixoto Granite encompasses monzogranite, biotitehornblende granodiorites, biotite tonalites and leucocratics that are isotropic equigranular to porphyritic textures. Elongated diorite enclaves are commonly observed ((1.792 \pm 2$) \mathrm{Ma}$; $\mathrm{Pb}-\mathrm{Pb}$ zircon dating of biotite monzogranite described in Paes de Bar$\operatorname{ros}(2007))$.

The Colider Suite is composed of felsic volcanic rocks bordering the Cachimbo graben (Lacerda Filho, 2004; Souza et al., 2005; Moreton \& Martins, 2005). These rocks are cut by Teles Pires granitic intrusions ((1.757 \pm 16$)$ Ma; Santos (2000); T TM $=2.10$ Ga; Lacerda Filho (2004)) and are covered by Paleoproterozoic shelf sediments (Leite \& Saes, 2003) of the Beneficente Group. The Beneficente Group in turn was deposited in a continental rift, morphologically depicted as a wide plateau oriented NW-SE, known as Serra do Cachimbo (Dardene \& Schobbenhaus, 2001).

The most recent sedimentary cover is represented by lateritic crusts and alluvial sediments constituted by coarse-grained sand, gravel and angular rock fragments. Because materials with significant gold concentration are coarser in these regions of the paleochannel, they became main targets for mining activities.

\section{Local geology}

Local geological units were defined based on geological superficial reconnaissance, descriptions of core samples, mapping of pits and exploratory mining galleries. The stratigraphic units are: (i) basement granitoids; (ii) tonalitic-granodioritic unit; (iii) cataclastic-mylonitic unit; and (iv) mafic to intermediate dikes. Such units were affected by hydrothermal processes which resulted in partial to total obliteration of the protolites, as well as in the production of filonean and disseminated ore bodies. The main hydrothermal alterations are quartz-sericite-pyrite alteration (QSP) and potassic alteration.

Basement medium-grained granitoids are of tonalitic to granodioritic compositions, displaying inequigranular porphyritic texture, a holocrystalline matrix, and anisotropy. Intensely chloritized Biotita with hematite in its borders is a main component of these rocks.

A Tonalitic-granodioritic Unit is essentially composed of rocks with tonalitic and granodioritic compositions, having quartz diorite and subordinated pegmatitic facies. Other characteristics that those rocks exhibit are: medium to coarse-sized grains; weak magnetism; isotropy; grayish green (due to chloritic alteration) to reddish pink (due to potassic alteration) matrix, with dark green dots. Locally, rocks of this Unit are truncated by finegrained pale pink aplite dikes. Quartz crystals exhibit high level of fracturing and recrystallization with pseudo-granoblastic features and sacaroidal texture, which indicates incipient deformation along cataclase zones.

A group formed by very fine to fine-grained mylonitic and cataclastic rocks display greenish tones with yellow to white spots. Anisotropy is evidenced by the strong foliation of chlorite crystals and stretching of quartz and feldspar crystals. Because quartz and plagioclase are observed to have been affected dynamic metamorphism, granodioritic and tonalitic rocks were most likely protolites of this group.

Dikes are observed to have intermediate or gabbroic compositions. Both types show abrupt and discordant contacts with the other described lithotypes, which is evidence of being younger. Their main characteristics are: dark green color due to strong chloritic alteration; aphanitic to fine phaneritic textures; and isotropy.

\section{Hydrothermal Alteration}

Various types and degrees of hydrothermal alteration affected those described lithotypes. A temporal evolution defined based on macroscopic relationships is schematically represented in Figure 2. High resolution photographs of those samples can be found in Agnoletto (2013).

Potassic alteration is pervasive and causes directional substitution of plagioclases by potassic feldspars from the edges of the igneous crystal to its center, producing engulfment textures with very fine hematite inclusions.

Silicification is a commonly well-developed observed form of alteration. Its main facet is the presence of medium to coarse interstitial grains of quartz, but some veins of fine recrystallized quartz are occasionally found.

Carbonation is basically represented by calcite production with subordinate chlorite and quartz, and sometimes substitutes the igneous plagioclase or the amphibole from gabbro.

Alteration with the presence of muscovite has muscovite 
+ sericite + quartz + chlorite association, being mainly interstitial and selective in a lower proportion. Small inclusions of fiber-radial muscovite are observed in the hydrothermal potassic feldspar.

Propylitic alteration is represented by the paragenesis of epidote, chlorite and calcite, which is of pervasive type and is occurs occasionally because it affects only the plagioclase.

QSP (quartz + sericite + pyrite) alteration is the most important from the prospective point of view, because it occurs near the filolean bodies and it is often presented as late veins with thickness up to $1.0 \mathrm{~cm}$, are continuous and composed mainly of quartz and rarely of potassic feldspar or calcite crystals. Additionally, this type of alteration may obliterate the granite, forming a type of disseminated ore.

Late calcite venules are more continuous than all other hydrothermal alteration types previously described. These venules appear as whitish to light pinkish thin strips in core samples.

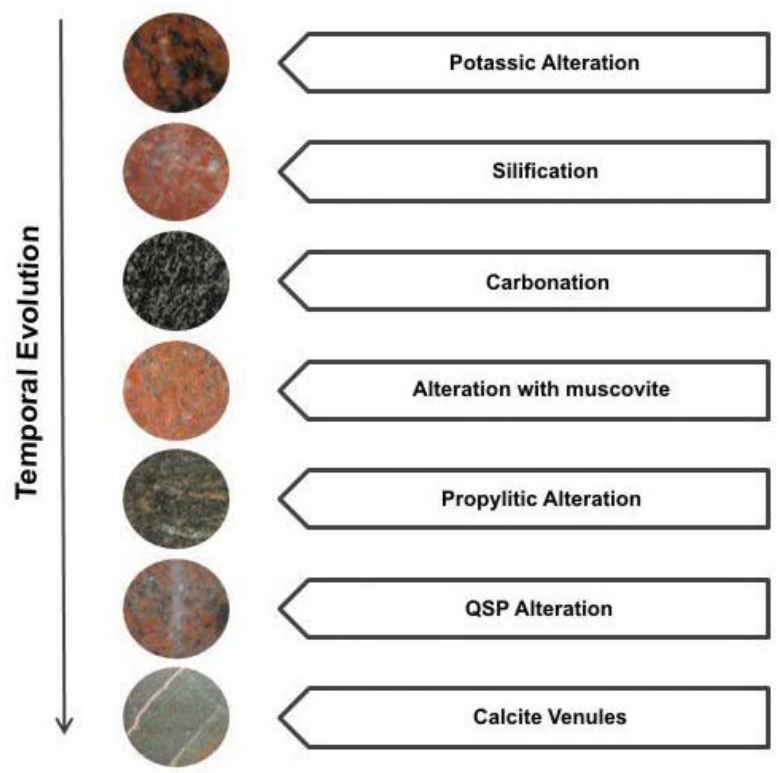

Figure 2 - Temporal evolution of hydrothermal paleosystem based on descriptions of core samples and a few outcrops in mining pits.

\section{MATERIALS AND METHODS}

Figure 3 shows the locations where the geophysical ground data were collected in the study area. IP/RES data and magnetic data measurements were spaced of $\sim 25 \mathrm{~m}$ and $12.5 \mathrm{~m}$, respectively.

\section{Resistivity (RES) and Induced Polarization (IP)}

We have used a IP/RES geoelectrical system that is composed of a 3000W power transmissor, fed by EM5000s Honda generator, and a multichannel receptor. This receptor and generator unit controls and measures the intensity of the applied electrical current and output voltage. Apparent resistivity and chargeability are simultaneously obtained from the output voltage. Essential to the IP measurements were the use of non-polarizable potential electrodes with $18 \%$ of porosity filled with a saturated solution of copper sulfate. Dipole-dipole electrode array with cables of lengths $25 \mathrm{~m}, 50 \mathrm{~m}, 75 \mathrm{~m}$ and $100 \mathrm{~m}$ was employed.

Resistivity methods are based on the injection of some amount of electrical current $I$ within the ground through two electrodes $A$ and $B$ and measurement of the output voltage $\Delta V$ between two other electrodes $M$ and $N$. The subsurface apparent resistivity $\rho_{a}$ is calculated using the expression $\rho_{a}=K \Delta V / I$, where $K$ is a geometrical parameter that depends on the chosen electrode array and involves the distances between $A, B, M$ and $N$ (e.g. Telford et al., 1990).

The time domain IP method, employed in this work, is based on the measurement of a potential $\left(V_{i}\right)$ integrated over a definite time interval of a transient current decay. If the integration time is very short and if the decay curve is sampled at various points, then values of the integral are measures of the potential existing at different times. For the transient current decay to occur, the induced electrical current is abruptly switched off after registering a primary voltage $V_{D C}$, where $D C$ stands for direct current. Apparent chargeability $\left(M_{a}\right)$ is proportional to the ratio $V_{i} / V_{D C}$. More details about fundamentals of the IP methods and its application to geophysical exploration can be found, for example, in Sumner (1984).

To calculate true resistivity $(\rho)$ and chargeability $(M)$ models from their respective measured apparent values, we have applied a smooth-model finite element inversion method as described in Maclnnes \& Zonge (1996). The method is implemented as in iterative algorithm available within the Geosoft Oasis Montaj ${ }^{\mathrm{TM}} \mathrm{IP}$ module. Smoothness constraints generate the smoothest model which also fits the observed data within an acceptable threshold. The algorithm attempts to minimize

$$
\left(\boldsymbol{J}^{T} \boldsymbol{J}+u \boldsymbol{F}\right) \boldsymbol{d}=\boldsymbol{J}^{T} \boldsymbol{g}-u \boldsymbol{F} \boldsymbol{r}
$$

where $\mathbf{F}$ is a smoothness matrix; $\mathbf{J}$ is a Jacobian matrix; $\mathbf{r}$ is a vector of the natural log of the true resistivities/chargeabilities; $\mathbf{d}$ is a vector of disturbances in $\mathbf{r}$, which is updated after each iteration; $u$ is a smoothness coefficient; $\mathbf{d}$ is a vector of disturbances; and $\mathbf{g}$ is a vector of differences between observed and calculated values. The $\mathbf{g}$ vector contains the differences between calculated and observed resistivities/chargeabilities. The outputs of the algorithm are matrices of resistivity and chargeability values with a fixed number of rows and columns. 


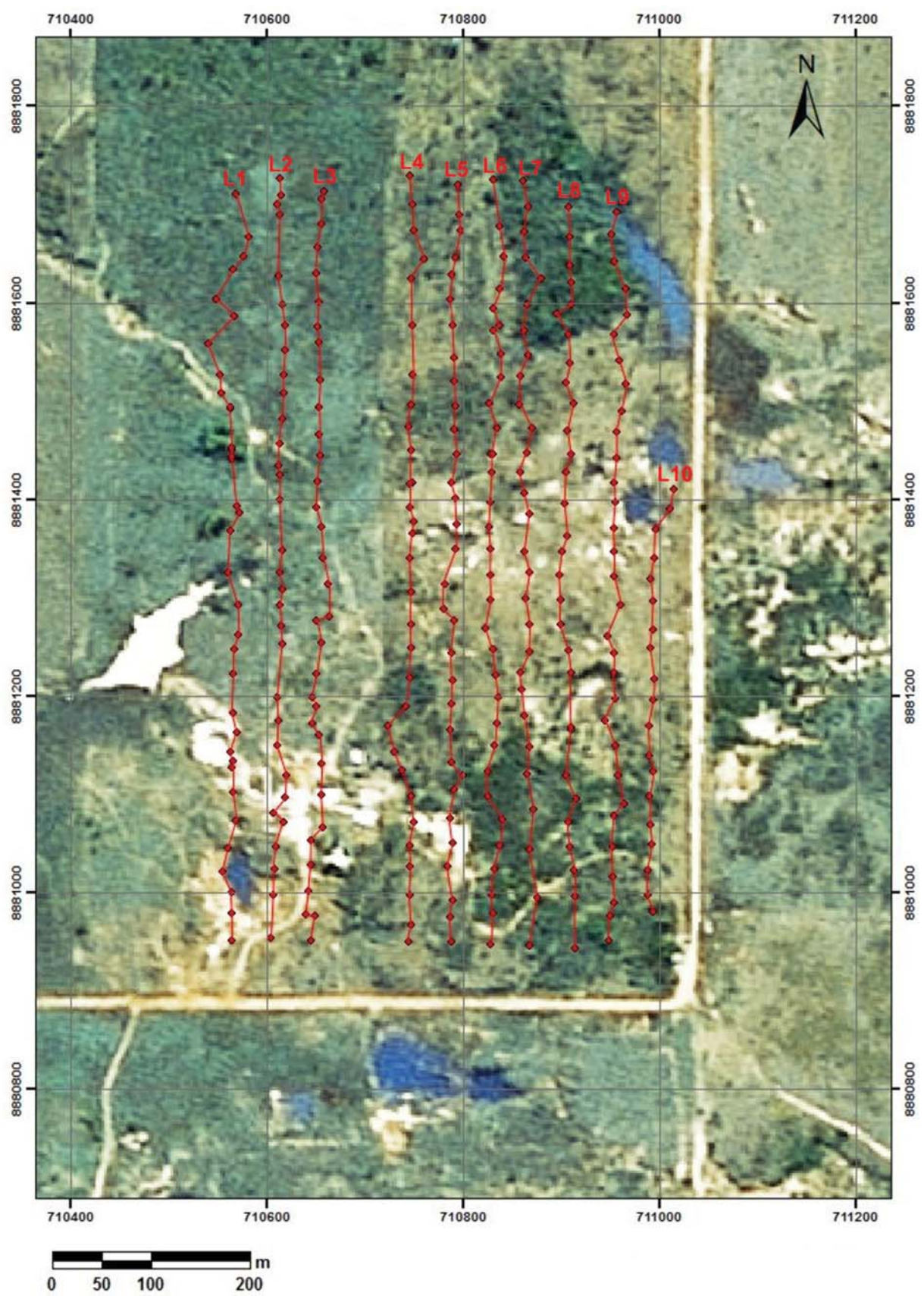

Figure 3 - Red points represent ground magnetic stations. Labels L1 to L10 identify approximate lines along which IP/RES data were acquired. Whitish areas in the background Google Earth image are active mining pits, whereas bluish areas are deactivated deep mining pits filled with water.

\section{Magnetometry}

A field survey was conducted using two proton-precession magnetometers that measures the amplitude of the total geomagnetic field with absolute accuracy of $\pm 1 \mathrm{nT}$. One of them was used in a fixed position to monitor the temporal diurnal variation and the other one was employed to make measurements on positions shown in Figure 3. The recorded diurnal variations were then removed from all field measurements. Total magnetic anomalies were obtained after removing a model of the International Geomagnetic Reference Field (IGRF; Finlay et al., 2010). The data was then interpolated using a minimum curvature algorithm (Briggs, 1974) and the resulting grid was upward continued to $100 \mathrm{~m}$ to remove very small scale features (e.g. Jacobsen, 1987). 
(A)

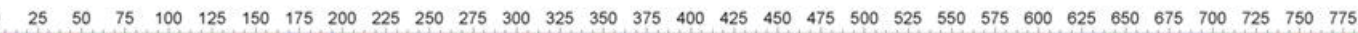

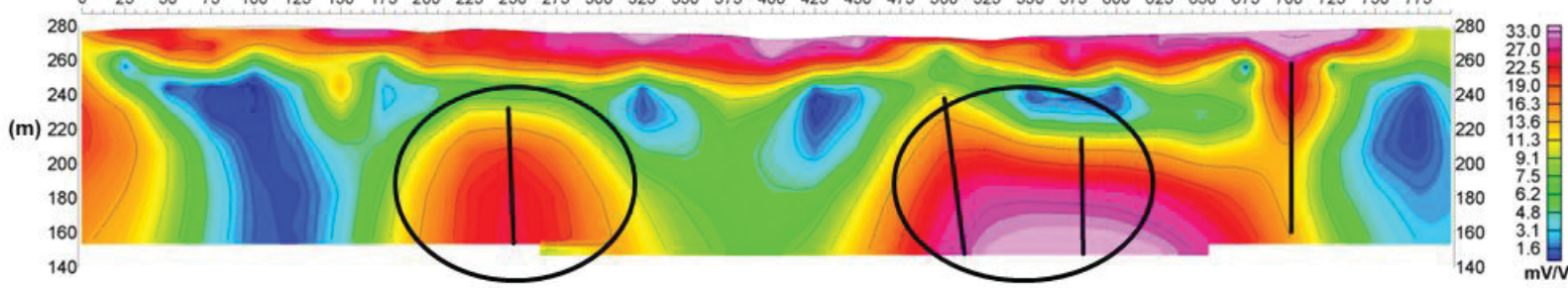

(B)

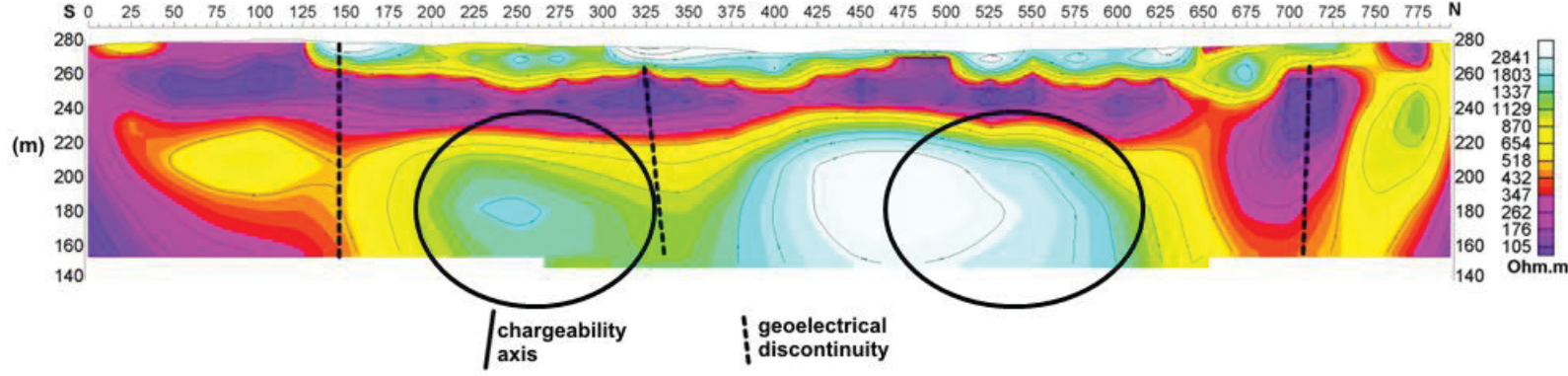

Figure 4 - Vertical sections (L4 in Fig. 3): (A) true chargeability; (B) true resistivity. Black ellipses outline target anomalies. Fault zones were inferred based on the black straight lines. Vertical axes are topographic elevations.

To highlight EW structural features along, the smoothed grid was filtered in two consecutive steps: (i) it was reduced to the equator using local magnetic inclination and declination equal to $-18.27^{\circ}$ and $-10.20^{\circ}$, respectively (e.g. Kis, 1990; Whitehead \& Musselman, 2007); (ii) a 0.5 degree N-S directional cosine filter (e.g. Ferraccioli et al., 1998). To correlate magnetic anomalies with the local lithologies, a map of the 3-D analytic signal amplitude (3D ASA; Roest et al., 1992) was produced. As correctly pointed out by Li (2006), this quantity is exactly equal to the amplitude of the total gradient. The 3D ASA centers anomalies over their causative bodies and it is particularly useful in this context because the sources of interest are shallow, the magnetic latitude is low $\left(\sim 1.19^{\circ} \mathrm{S}\right)$ and remanent magnetization may be present (Li, 2006).

\section{RESULTS AND DISCUSSION}

\section{IP and RES}

Ten depth sections with values of $\rho$ and $M$ were obtained. One of them, Line $L 4$, is shown in Figure 4 . The observed general pattern from top to bottom is: a shallow polarizable and resistive zone, which is related to $\mathrm{a} \sim 50 \mathrm{~m}$ thick regolith and saprolite of the mining area; a high conductive non-polarizable layer; and big lenses of high $M$ and $\rho$ values immersed in an otherwise low background. Such lenses are target anomalies, which may have gold metallogenetic potential. The high chargeability are due to the intense QSP alteration containing thin disseminated pyrite and tabular minerals such as sericite and quartz, while the high resistivity is caused by the host granodioritic rock which has an intense pervasive silicification. Some fault zones were inferred and eventually confirmed by geological mapping of open-pits.

Concerning the horizontal sections, the depth levels of investigation in meters were: $\mathrm{n} 1=0, \mathrm{n} 2=8, \mathrm{n} 3=19, \mathrm{n} 4=32$, $n 5=48, n 6=68, n 7=94$ and $n 8=127$. Vertical distance between these levels depends on the distances between current and potential electrodes, which in this case was $25 \mathrm{~m}$. Level $\mathrm{n} 1$ does not show any prospective potential because it reflects regolith and intense mining activity. Levels $\mathrm{n} 2$ and $\mathrm{n} 3$ show continuity of highly polarizable and resistive strata on the setentrional, central and meridional portions of the study area. Those maps, in conjunction with that of Level n4 (Fig. 5A), represent polarizable covers that are correlated to potassified and silicified granodioritic saprolite with basic xenoliths.

The most prominent anomaly at Levels $\mathrm{n} 4$ and $\mathrm{n} 5$ are in a round-shaped zone of high chargeability ( $>16,4 \mathrm{mV} / \mathrm{V})$ and mid to high resistivity values $( \pm 5000 \mathrm{hm} . \mathrm{m})$ on the east-center portion of the section (Figs. 5A and 5B). The anomaly persists down to Level n8, and is related to a small granitic body with disseminated sulfides and moderated silification, which is important to gold mineralization in Flor da Serra area. 


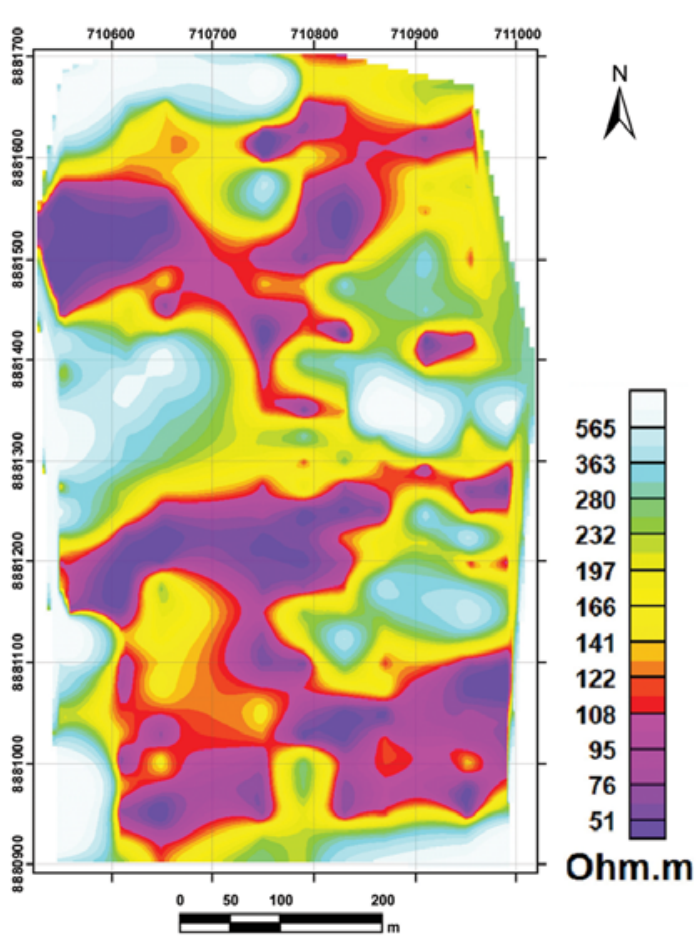

(A)

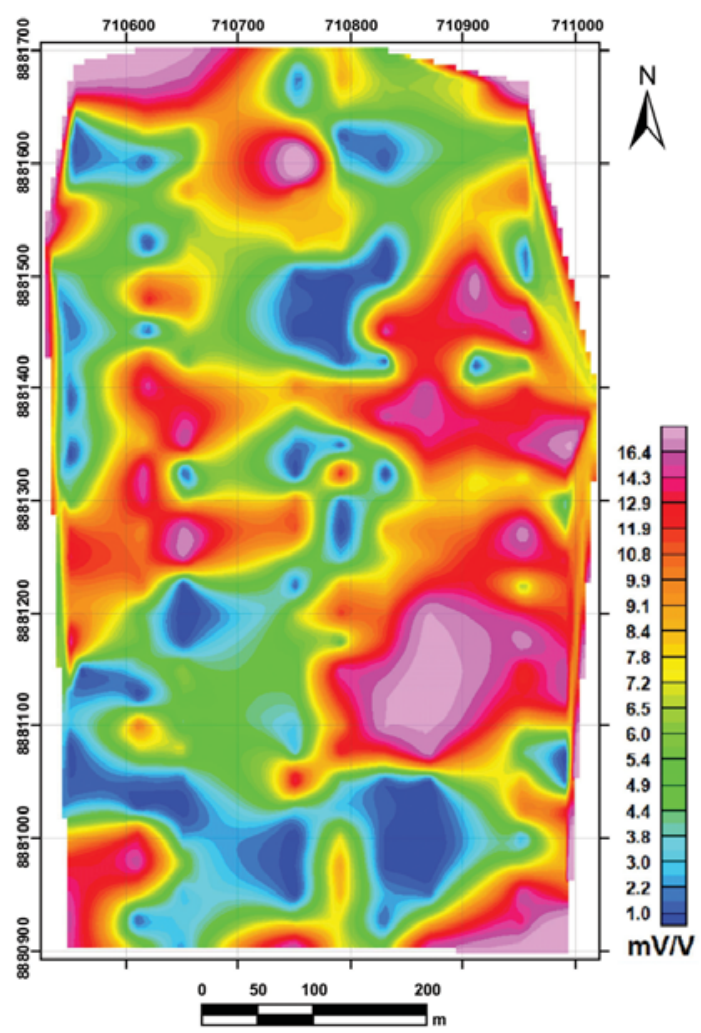

(C)

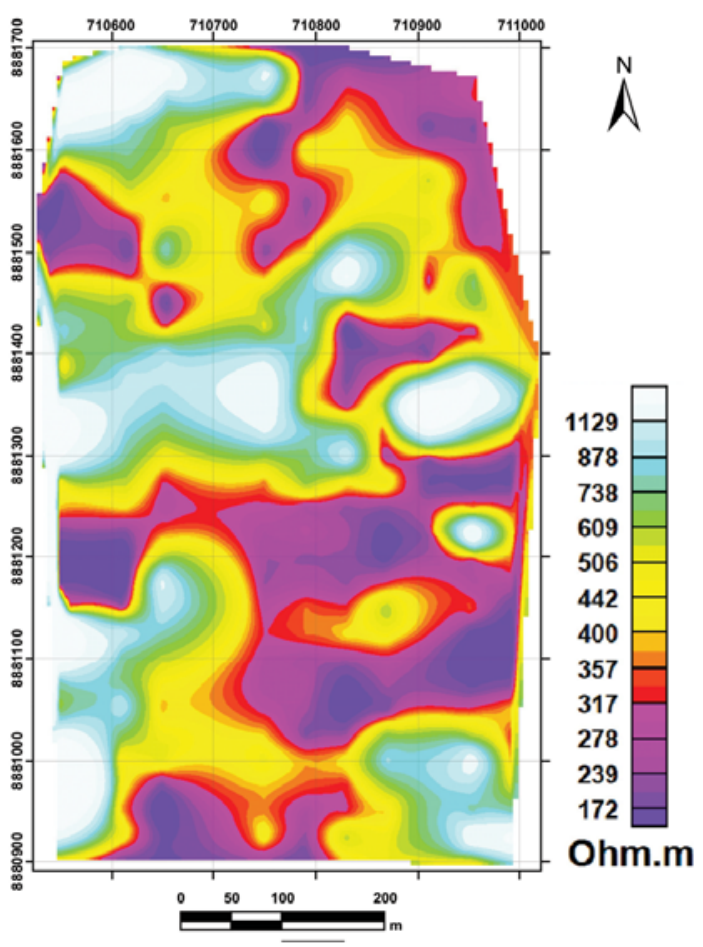

(B)

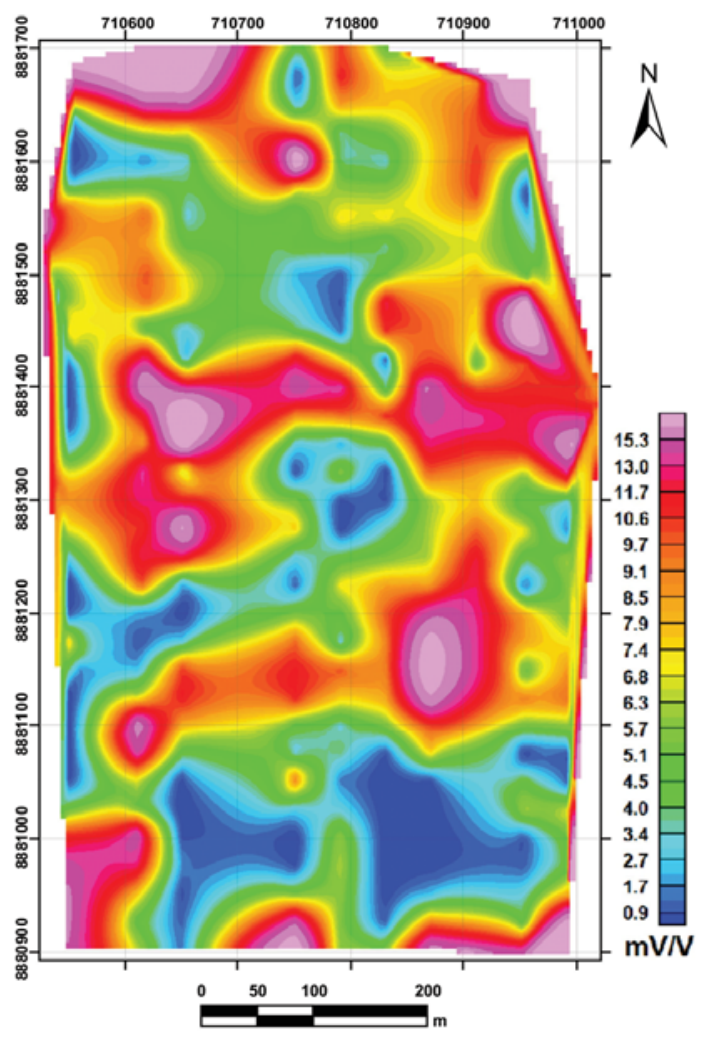

(D)

Figure 5 - Horizontal sections at Levels $n 4=32 \mathrm{~m}$ and $n 5=48 \mathrm{~m}$. (A) and (B): resistivity; (C) and (D): chargeability. 


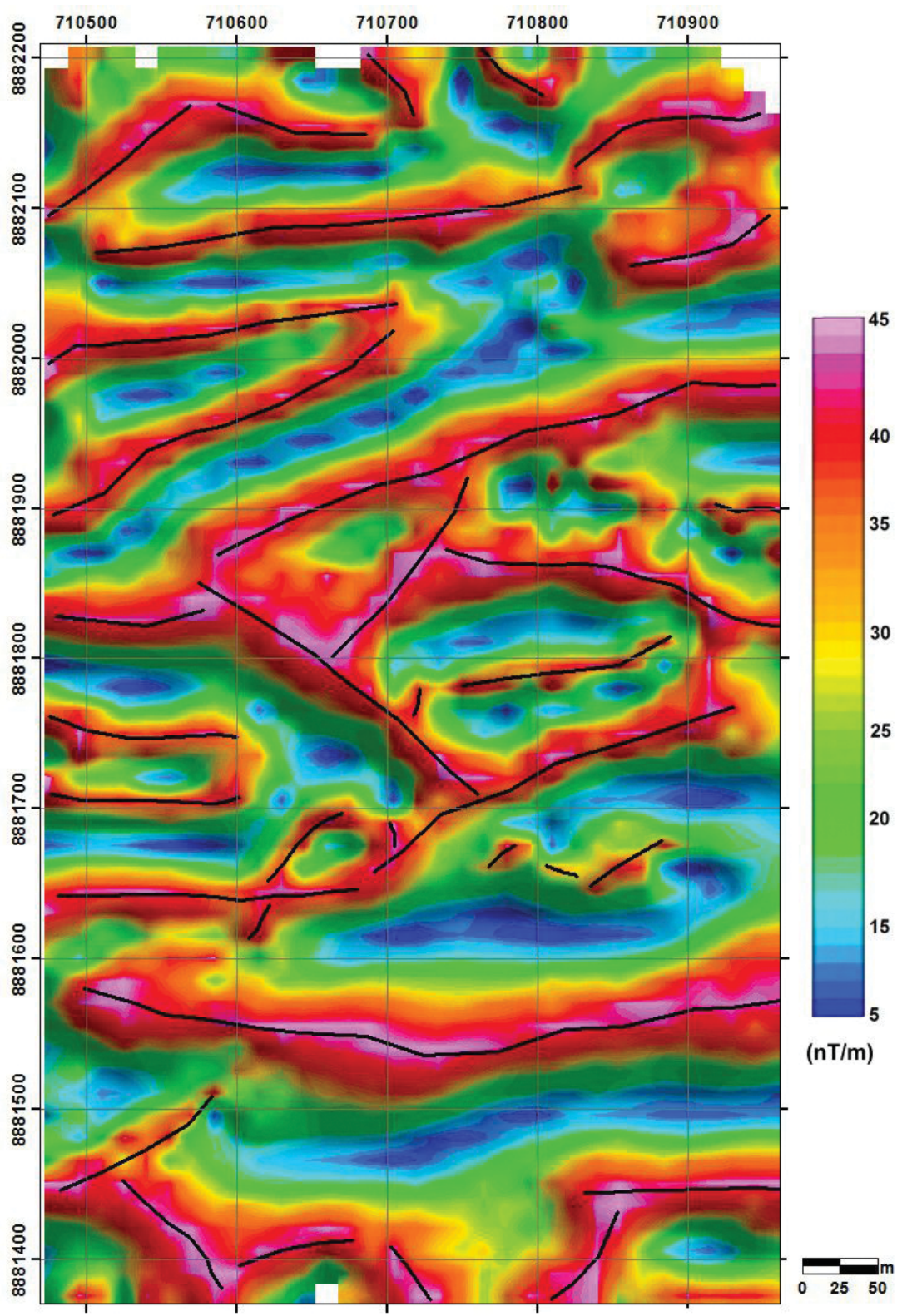

Figure 6 - Magnetic structures interpreted from the upward continued and directionally filtered map of magnetic anomalies reduced to the equator.

The lowest Levels n6, n7 and n8 show similar attenuated anomaly values and spatial distributions of $M$ and $\rho$. An elongated NE-SW anomaly is observed on the central portion of their correspondent horizontal sections. Such anomalies can be correlated to the youngest brittle structures with subordinated quartz-sulfide veins.

\section{Magnetometry}

Most of the magnetic lineaments shown in Figure 6 are oriented $\mathrm{E}-\mathrm{W}$ and are correlated with known mylonitic shear zones that contain filonean gold mineralizations (Barbuena et al., 2013). Those lineaments were manually tracked on the upward continued, directionally filtered map of magnetic anomalies reduced to the equator. The main granitic body in the study area is in between such structures. Some NE-SW lineaments are correlated to brittle shear zones conjugated to E-W structures through a preferred sinistral kinematics.

Gold deposits fill fractures that are conditioned to shear megastructures, which in turn affected those basement granitoids; or they are related to superimposed Paleoproterozoic granitogenic 
activities with gold remobilization associated to phases of intense hydrothermalism (Paes de Barros, 2007).

Because rocks of basic composition with disseminated magnetite and ilmenite are dominant in the study area, most of the magnetic anomalies are high and positive. In the ASA map of Figure 7, we observe two main distinct magnetic domains labelled $A$ and $B$. Domain $A$ is on the central-eastern portion of the map and its anomalies are relatively low $(<1 \mathrm{nT} / \mathrm{m})$. This domain is correlated to a granitic stock of granodioritic-tonalitic composition, which is isotropic, as observed macroscopically on core samples. Within Domain A there is also a relatively high triangular magnetic anomaly (>1 nT/m), suggesting the presence of a basement xenolith or a granitic intrusion of a more dioritic composition (Label A2).

Magnetic anomalies of Domain B are generally higher. Domain B2 depicts a large positive anomaly on the southern portion of the map, in contrast with a more heterogeneous distribution of anomalies on the northern portion. This pattern is correlated to the area mapped as basement granitoids, which also are predominantly tonalitic and weakly granodioritic. However, there are areas of high concentration of magnetite, talk-chlorite schists, amphibolites and metapyroxenites (Paes de Barros 2007). There is also the possibility dioritic to mafic granitic intrusion to explain A2 anomaly.

The contact between domains $A$ and $B$ are marked by brittleductile shear zones associated with regional structures relevant to the geodynamic evolution of the AFGP. Those structures are evidenced in the magnetic maps, because such magnetic discontinuities are very expressive. Outcrops on the edges of deactivated open mining pits confirm the presence of such structures.

\section{Integrated interpretation}

Chargeability and resistivity trends interpreted at Level $\mathrm{n} 7=$ $94 \mathrm{~m}$, together with magnetic structures, are shown in an integrated map (Fig. 8). Geoelectrical anomalies are smooth at this level and reflect a more homogeneous geological pattern that may have some fractures and mineralized veins, or have suffered hydrothermal alteration. Smoothness of the models was controlled during IP/RES inversion. Possible gold exploration targets, depicted as yellow dots in Figure 8, were established based on the following three criterions that should be simultaneously satisfied: (i) proximity to magnetic structures; (ii) positioning along trends of high $M$ and $\rho$ values; and (iii) proximity to the boundaries of Domains A and A2. Such criterions were validated based on detailed local analysis of samples from mining pits (Agnoletto, 2013).
Disseminated mineralizations and stockworks hosted by granitic bodies were observed in the field, besides quartz veins/venules associated with lithological contacts, mainly between the granitic intrusion (white contour in Fig. 8) and more basic portions of the basement granitoids. This is expected in a brittle-ductile regime in granitic terrains; however, further studies are needed to better understand how such structures relate to a hydrothermally altered granitic body.

\section{CONCLUSIONS}

The following conclusions were drawn based on the results presented in this paper:

(i) Our geological mapping of the Intrusive Suite of Flor da Serra suggests that the area covered by those rocks is narrower than that mapped in the work of Moreton \& Martins (2005);

(ii) NW structures are associated with the eastern regional framework of the AFGP and EW structures occurs more frequently, the latter being associated with a preferred sinistral kinematics of deep roots that hosts gold-bearing sulfide quartz veins and also delineates granitic bodies;

(iii) The weathering profile of the Flor da Serra region is enriched in clay minerals, which made it possible to be detected by the induced polarization method. The interface between saprolite and bedrock is identified at about $50 \mathrm{~m}$ depth;

(iv) The positive anomalous regions of chargeability and resistivity are associated with the main hydrothermal zones related to gold mineralizations;

(v) Potential gold exploration targets can be defined based on an integrated interpretation of: magnetic structures; regions of relatively high chargeability and resistivity; boundary zone of a possible granitic intrusion delimited based on magnetic data.

\section{ACKNOWLEDGEMENTS}

We are thankful to: Conselho Nacional de Desenvolvimento Científico e Tecnológico (CNPq) for the financial support through Ethiane's Masters schoolarship; Laboratório de Pesquisas em Geofísica Aplicada (LPGA) of the Department of Geology of the Universidade Federal do Paraná (UFPR) for providing all the geophysical equipment; Professor Roberto Perez Xavier for valuable discussions about our results and interpretations. 


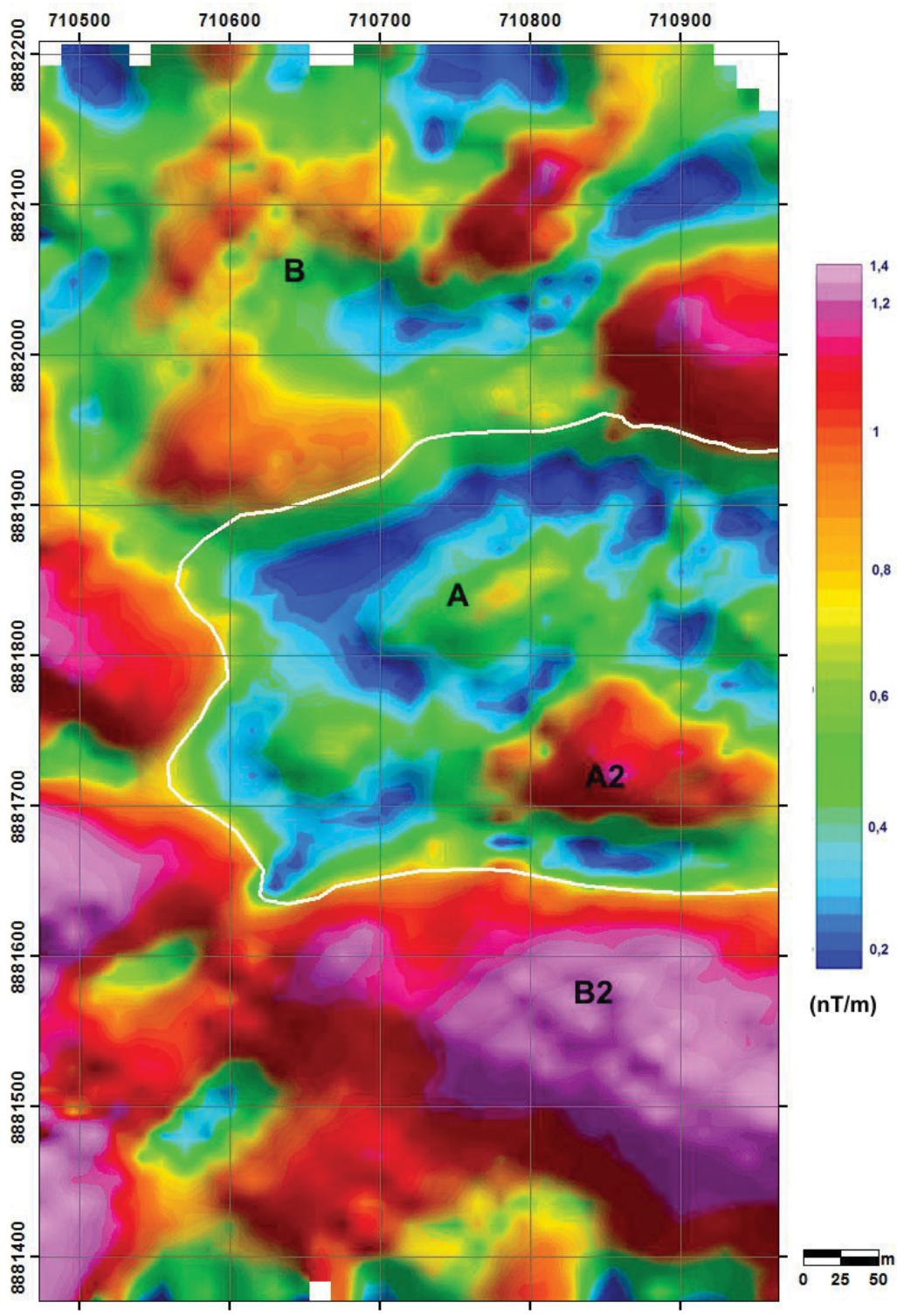

Figure 7 - ASA map interpreted magnetic domains. Domains A and A2 represent a granodioritic-tonalitic Unit and Domains B and B2 represent an heterogeneous basement (granitoids).

\section{REFERENCES}

AGNOLETTOE. 2013. Caracterização litológica e identificação de alvos exploratórios na região de Flor da Serra, Província Aurífera Alta Floresta (MT), utilizando dados magnéticos e geoelétricos. Master dissertation. Instituto de Geociências, Universidade Estadual de Campinas, Campinas, São Paulo, Brazil, 118 pp.

ASSIS R. 2011. Depósitos auríferos associados ao magmatismo granítico do setor leste da Província de Alta Floresta (MT), Cráton Amazônico: tipologia das mineralizações, modelos genéticos e implicações prospectivas. Master dissertation. Instituto de Geociências, Universidade Estadual de Campinas, São Paulo, Brazil, 456 pp.
AUSTIN JR, SCHMIDT PW \& FOSS CA. 2013. Magnetic modeling of iron oxide copper-gold mineralization constrained by $3 \mathrm{D}$ multiscale integration of petrophysical and geochemical data. Cloncurry District, Australia. Interpretation, 1(1): T63-T84.

BARBUENA D, DE SOUZA FILHO CR, LEITE EP, MIGUEL JUNIOR E, ASSIS RR, XAVIER RP, FERREIRA FJF \& PAES DE BARROS AJ. 2013. Airborne geophysical data analysis applied to geological interpretation in the Alta Floresta Gold Province, MT. Brazilian Journal of Geophysics, 31(1): 169-186.

BRIGGS IC. 1974. Machine contouring using minimum curvature. Geophysics, 39(1): 39-48. 


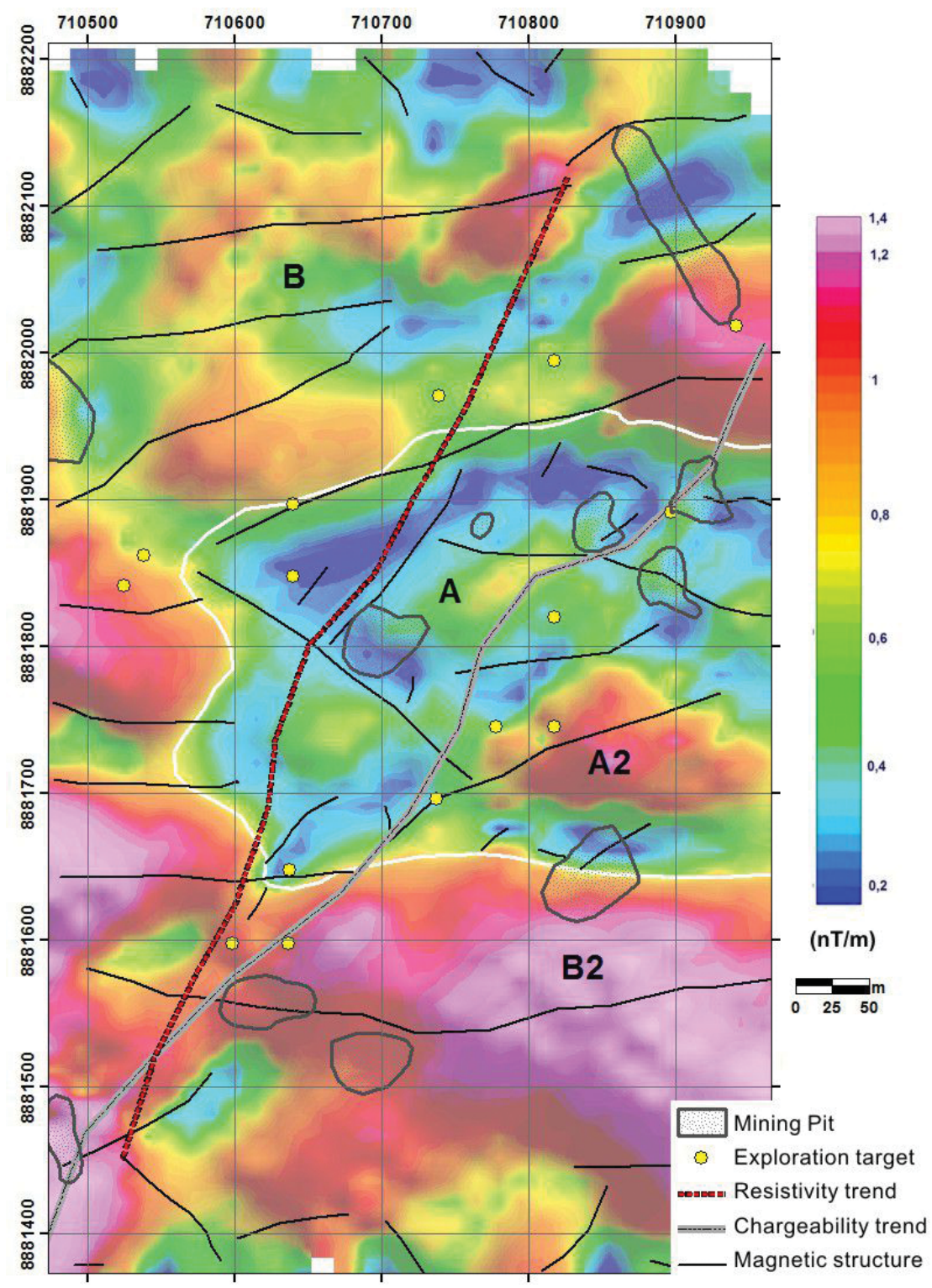

Figure 8 - Integrated map depicting: main magnetic structures; open mining pits; $M$ and $\rho$ trends; possible gold exploration targets (yellow dots). Labels are the same as in Figure 7.

DANESHVAR SAEIN L, RASA I, RASHIDNEJAD OMRAN N, MOAREFVAND P \& AFZAL P. 2012. Application of concentration-volume fractal method in induced polarization and resistivity data interpretation for Cu-Mo porphyry deposits exploration, case study: Nowchun Cu-Mo deposit, SE Iran. Nonlinear Processes in Geophysics, 19(4): 431-438.

DARDENNE MA \& SCHOBBENHAUS C. 2001. The metallogenesis of the South American platform. In: CORDANI UG, MILANI EJ, TOMAZ FILHO A \& CAMPOS DA (Eds.). Tectonic Evolution of South America. Rio de Janeiro: 31st International Geological Congress, Rio de Janeiro. pp. 755-850.

FERRACCIOLI F, GAMBETTA M \& BOZZO E. 1998. Microlevelling pro- cedures applied to regional aeromagnetic data: an example from the Transantarctic Mountains (Antarctica). Geophysical Prospecting, 46(2): 177-196.

FINLAY CC, MAUS S, BEGGAN CD, BONDAR TN, CHAMBODUT A, CHERNOVA TA \& ZVEREVA TI. 2010. International geomagnetic reference field: the eleventh generation. Geophysical Journal International, 183(3): 1216-1230

HOLDEN EJ, DENTITH M \& KOVESI P. 2008. Towards the automated analysis of regional aeromagnetic data to identify regions prospective for gold deposits. Computers \& Geosciences, 34(11): 1505-1513. 
IRVINE RJ \& SMITH MJ. 1990. Geophysical exploration for epithermal gold deposits. Journal of Geochemical Exploration, 36(1): 375-412.

JACOBSENBH. 1987. A case for upward continuation as a standard separation filter for potential-field maps. Geophysics, 52(8): 1138-1148.

JAIN S. 1988. Total magnetic field reduction - The Pole or Equator? A model study. Canadian Journal of Exploration Geophysics, 24(2): 185192.

JANG H, PARK S \& KIM HJ. 2014. A simple inversion of inducedpolarization data collected in the Haenam area of Korea. Journal of Geophysics and Engineering, 11(1): 015011.

KIS KI. 1990. Transfer properties of the reduction of magnetic anomalies to the pole and to the equator. Geophysics, 55(9): 1141-1147.

LACERDA FILHO JV DE. 2004. Geologia e recursos minerais do estado de Mato Grosso. Escala 1:1.000.000. CPRM (Convênio CPRM/SICME). CDD 558. Goiânia, Goiás, Brazil.

LEITE EP \& DE SOUZA FILHO CR. 2009. Artificial neural networks applied to mineral potential mapping for copper-gold mineralizations in the Carajás Mineral Province, Brazil. Geophysical Prospecting, 57: 1049-1065.

LEITE JAD \& SAES GS. 2003. Geocronologia Pb/Pb de zircões detríticos e análise estratigráfica das coberturas sedimentares proterozóicas do sudoeste do Cráton Amazônico. Geologia USP, Série Científica, 3(1): $113-127$.

LI X. 2006. Understanding 3D analytic signal amplitude. Geophysics, 71(2): L13-L16.

MACINNES S \& ZONGE K. 1996. Two-dimensional inversion of resistivity and IP data with topography. In: 102nd Annual Northwest Mining Association Convention. Spokane, WA, 17 pp. Available on: <http:// zonge.com/wp-content/uploads/2013/06/MIN_NWMA19963.pdf > . Access on: August 10, 2014.

MEJU MA. 2002. Geoelectromagnetic exploration for natural resources: models, case studies and challenges. Surveys in Geophysics, 23(2-3): 133-206.

MIGUEL Jr E. 2011. Controle estrutural das mineralizações auríferas e idade U-Pb das encaixantes ao longo do lineamento Peru-Trairão: Província Aurífera Alta Floresta, Mato Grosso. Master dissertation. Instituto de Geociências, Universidade Estadual de Campinas, Campinas, São Paulo, Brazil, 66 pp.

MORETON LC \& MARTINS EG. 2005. Geologia e recursos minerais da Folha Vila Guarita - Folha SC.21-Z-B. CPRM - Estado de Mato Grosso. Escala 1:250.000. Brasília, Distrito Federal, Brazil.

MOURA MA, BOTELHO NF, OLÍVIO GR \& KYSER TK. 2006. Graniterelated Paleoproterozoic, Serrinha gold deposit, Southern Amazonia,
Brazil: hydrothermal alteration, fluid inclusion and stable isotope constraints on genesis and evolution. Economic Geology, 101(3): 585-605.

OLDENBURG DW, YAOGUO L \& ELLIS RG. 1997. Inversion of geophysical data over a copper gold porphyry deposit: A case history for Mt. Milligan. Geophysics, 62(5): 1419-1431.

PAES DE BARROS AJ. 2007. Granitos da região de Peixoto de Azevedo - Novo Mundo e mineralizações auríferas relacionadas - Província Aurífera Alta Floresta (MT). Doctorate thesis. Instituto de Geociências, Universidade Estadual de Campinas, Campinas, São Paulo, Brazil, $154 \mathrm{pp}$.

RANJBAR H, HASSANZADEH H, TORABI M \& ILAGHI 0. 2001. Integration and analysis of airborne geophysical data of the Darrehzar area, Kerman Province, Iran, using principal component analysis. Journal of Applied Geophysics, 48(1): 33-41.

ROEST WR, VERHOEF J \& PILKINGTON M. 1992. Magnetic interpretation using the 3-D analytic signal. Geophysics, 57(1): 116-125.

SANTOS JOS. 2006. A compartimentação do Cráton Amazonas em províncias: avanços ocorridos no período 2000-2006. In: Simpósio de Geologia da Amazônia, 9., Belém, Brazil, Proceedings, SBG Núcleo Norte, CD-ROM.

SOUZA JO, FRASCA AAS \& OLIVEIRA CC. 2005. Geologia e Recursos Minerais da Província Mineral de Alta Floresta (Relatório Integrado). Brasília, Brasil: CPRM-Programa Levantamentos Geológicos Básicos do Brasil (PLGB), 159 pp.

SUMNER JS. 1984. Principles of induced polarization for geophysical exploration. Elsevier, Amsterdam, The Netherlands, 292 pp.

TASSINARI CCG \& MACAMBIRA MJB. 1999. Geochronological provinces of the Amazonian Craton. Episodes, 22(3): 174-182.

TELFORD WM, GELDART LP \& SHERIFFRE. 1990. Applied Geophysics, 2nd ed., Cambridge University Press, New York, USA, 792 pp.

VITORIO JA. 2010. A suíte granítica Teles Pires da Província Aurífera Alta Floresta: Características petrográficas, geoquímicas e implicações metalogenéticas. Instituto de Geociências, Universidade Estadual de Campinas, São Paulo, Brazil. Relatório PIBIC/CNPq, 20 pp.

WHITEHEAD N \& MUSSELMAN C. 2007. Montaj MAGMAP Filtering: 2D Frequency Domain Processing of Potential Field Data 6.4. Geosoft Inc., Canada, 76 pp.

ZHAO J, CHEN S, ZUO R \& CARRANZAEJM. 2011. Mapping complexity of spatial distribution of faults using fractal and multifractal models: vectoring towards exploration targets. Computers \& Geosciences, 37(12): 1958-1966. 


\section{NOTES ABOUT THE AUTHORS}

Ethiane Agnoletto. Geologist (Universidade Federal do Mato Grosso, 2010), Master in Geosciences (Universidade Estadual de Campinas, 2013). Currently, is working as a mining geologist at Biominer Mineração.

Emilson Pereira Leite. Geophysicist (Universidade de São Paulo, 1997), Master in Geophysics (Universidade de São Paulo, 2000), Ph.D. in Geophysics (Universidade de São Paulo, 2005). Currently, is working as a Professor in the Institute of Geosciences at the Universidade Estadual de Campinas. Holds a scientific productivity grant from the Conselho Nacional de Desenvolvimento Científico e Tecnológico (Brazilian National Council for Scientific and Technological Development - CNPq). 